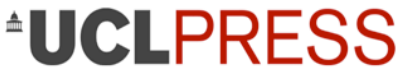

\section{The Journal of the Sylvia Townsend Warner Society}

\section{'Introduction' to Kingdoms of Elfin (Handheld Press, 2018)}

Ingrid Hotz-Davies ${ }^{1, *}$

How to cite: Hotz-Davies, I. "Introduction" to Kingdoms of Elfin (Handheld Press, 2018).' The Journal of the Sylvia Townsend Warner Society, 2019, 18(2), pp. 1-17. DOI: https://doi.org/10.14324/111.444.stw.2019.10

Published: 12 April 2019

\section{Peer Review:}

This article has been peer reviewed through the journal's standard double blind peer-review, where both the reviewers and authors are anonymised during review.

\section{Copyright:}

(C) 2019, Ingrid Hotz-Davies. This is an Open Access article distributed under the terms of the Creative Commons Attribution License (CC-BY) 4.0 https://creativecommons.org/licenses/by/4.0/, which permits unrestricted use, distribution and reproduction in any medium, provided the original author and source are credited • DOI: https://doi.org/10.14324/111.444.stw.2019.10

\section{Open Access:}

The Journal of the Sylvia Townsend Warner Society is a peer-reviewed open access journal.

\footnotetext{
*Correspondence: ingrid.hotz-davies@uni-tuebingen.de

${ }^{1}$ University of Tübingen, Germany
} 


\title{
'Introduction' to Kingdoms of Elfin (Handheld Press, 2018)
}

\author{
Ingrid Hotz-Davies
}

\begin{abstract}
Originally conceived of as an introduction to a new edition of Sylvia Townsend Warner's Kingdoms of Elfin (Handheld Press, 2018), this article provides an overview of the place of Kingdoms of Elfin (1977) in Sylvia Townsend Warner's oeuvre and life, placing it in the final phases of her life as an astonishing new departure. In Kingdoms, Warner experiments with the excision of affect from the narrative process, producing stories which construct the narrative voice uncompromisingly as a voice of observation rather than identification. The playing field on which this is carried through is nothing less than a whole new fictional universe in the form of meticulously worked-out 'Elfin' worlds. The narratives' observational stance unfolds itself as a disinterested ethnography of the strangeness of behaviours both human and non-human, radically decentring human perceptions and moral convictions in the process.
\end{abstract}

Keywords Warner; fairy stories; ethnography; Kingdoms of Elfin

Sylvia Townsend Warner started with the short story 'Something Entirely Different' in the early 1970s, and from then on wrote in an astonishing rush, producing more and more stories set in the world of fairies. In this way, after the devastating loss of her beloved partner Valentine Ackland, and towards the end of her own life, Warner entered new territory: Elfindom. She was keenly conscious that she was embarking on a new journey, a challenge and an adventure. As she remarked in an interview, 'I suddenly looked round on my career and 
thought, "Good God, I've been understanding the human heart for all these decades. Bother the human heart, I'm tired of the human heart. I'm tired of the human race. I want to write about something entirely different."'1 To William Maxwell, her friend, fellow writer and long-time editor from the New Yorker, she wrote that she was pleased that the New Yorker would print 'Something Entirely Different' (renamed 'The One and the Other' in Kingdoms of Elfin): 'I admire the story myself, and feel justified by it: justified, I mean, in supposing that something entirely different is still possible for me, that I can still pull an unexpected ace out of my sleeve.' ${ }^{2}$

The 16 stories that were for the most part first published in the New Yorker would come together in Kingdoms of Elfin (1977), the last of her books that Warner would see published in her lifetime. They are indeed different, though her willingness to be intrigued by the fairy world dates back to the 1920s, anticipating much of what was to concern her in the 1960s and 1970s. ${ }^{3}$ Warner was prodigiously productive and versatile, as well as a consistently stubborn writer. Her works include seven novels, roughly 150 short stories, many essays and lecture scripts, a biography, and the moving collection of the letters exchanged over a lifetime between herself and Valentine Ackland, which she prepared for publication after Ackland's death.

Kingdoms of Elfin displays Warner's characteristic command of meticulous narrative technique, but it breaks a fundamental rule for fiction. Warner insisted that these stories were skeletal writing: 'there is practically no flesh on it at all, and no breath of human kindness. But it seems to me that the bones live. ${ }^{4}$ Kingdoms of Elfin is an experiment in reduction: the excision of all empathy from the narrative. The stories do feature creatures endowed with a variety of emotions, and empathy may well reside in the heart of the reader, but at no point must there be any 'breath of human kindness' in the narrative itself. 'The One and the Other' gives us a good sense of what lies ahead in its opening paragraph:

When the baby was lifted from the cradle, he began to whimper. When he felt the rain on his face, he began to bellow. 'Nothing wrong with his lungs,' said the footman to the nurse. They spread their wings, they rose in the air. They carried the baby over a birchwood, over an oakwood, over a firwood. Beyond the firwood was a heath, on the heath was a grassy green hill. 'Elfhame at last,' said the nurse. They folded their wings and alighted. A door opened in the hillside and they carried the 
baby in. It stared at the candles and the silver tapestries, left off bellowing, and sneezed. $(1)^{5}$

Within a few lines, we come to understand that what appears comfortably familiar and even dated - a baby, a footman, a nurse - is no such thing, as this baby is being taken away by creatures who take to their wings as easily as you or I would walk down a road. The baby, at first a 'he', very subtly mutates into an 'it', and a little further on we learn that the first procedures to be visited on this baby are invasive and denaturing ('denaturing', that is, from a human perspective), designed to 'abate the human smell' (1) and finally render 'it' 'sufficiently inhumanized to be given its new name' (2). Within a few sentences, ordinary points of orientation come loose, and this disorientation is pursued systematically to the story's end as we follow the changeling human in Elfhame as well as the changeling fairy among the humans. The story is a hall of mirrors in which the different sides reflect each other disconcertingly: ${ }^{6}$ we see humans from fairy perspectives and fairies through human eyes, and the environments of both changelings are defamiliarised and challenged by their very presence.

When Adam, the fairy child left in place of the baby, is told that the cat that suckled him as a baby has died, his first response is to dissect it in order to understand mortality, a very reasonable obsession for someone half remembering the near-immortality of his species. The family's servant Ailie is dismayed, but how sentimental should one's attachment be to a suckling cat, even if one weren't an elf? Throughout these stories, casual cruelties abound in both worlds - famines, wars, exploitation among the humans and the cruelties of aristocratic boredom among the fairies. These arise sometimes from veritable inhumanity (though what can '(in)human' mean in these stories?) and sometimes out of the necessities of life. In 'The One and the Other', for example, the baby's mother fails to notice the theft of her baby because 'she was busy making sausage meat and pork pies that day; and this was not her first child, to be studied like a nonpareil. Indeed, it was her ninth, though not all of them had lived' (2). The fairy baby left behind in the cradle needs to be de-elfinised for the transition as much as the changeling needs to be inhumanised, in his case by having his wings 'extirpated' and his blood 'dosed with an elixir of mortality, compounded from tears and excrement of changelings', and finally we come to understand one of the mysteries of spiritualism: 'The transfers die, but tardily and with extreme difficulty, and some have been known to hover briefly in the air - a phenomenon called levitation and usually ascribed to saintliness' (6). 
All of this is described with profound detachment. We are made observers through the eyes of a narrator who may slip in and out of the characters' minds, or choose to stay outside them altogether, but who at no point gives us the luxury of feeling with these characters. We may envy some of them for some of the time, find others disgusting, sigh at human or Elfin folly, but at no point are we invited to 'identify', that staple of so much fiction, with any of them. So detached is this narrative voice that at least one reader has wondered whether the narrator might, at least part of the time, actually be a fairy. ${ }^{7}$ In their contents, too, the stories exhibit a marked degree of narrative coldness in that they eschew poetic justice, providence or morally centred vision. Moral judgement is already prevented by the narrative voice remaining an observer, sometimes an amused one, but never one that judges, an activity of which Warner herself was severely critical. She thought that the injunction 'Don't point!' was 'sound advice and should be given more often and to all ages' ${ }^{8}$

In 'The Blameless Triangle', for example, we follow a group of fairies who have little value in their German home kingdom of Wirre Gedanken, as they leave to wander among humans. In this they are not unlike the Grimm Brothers' tale of the 'Musicians of Bremen', four downtrodden creatures, a donkey, a rooster, a cat and a dog, who win for themselves a home through solidarity, courage and guile. In contrast, Warner's 'discards' - Ludo, Moor, Tinkel, Nimmerlein and Banian - search for a place where they might engage in the 'Socratic scrabbling' (44) which they have come to enjoy after their abandonment by their court, a place where they might follow the 'wish to meditate' which 'took hold of them' (45). They find a 'disused chapel on a lonely hillside' which is 'dirty and cluttered with Christian odds and ends' (46-7), but which would do. In the Grimms' template of the story, finding this refuge would be the ending, the rejects having found a home, but Warner makes this their new beginning. We see the Brotherhood of the Blameless Triangle learn to meet their daily material needs, squabble Socratically, inadvertently cause the death of a priest who comes to exorcise their occupation of the church, and travel through south-eastern Europe where they observe human activities. 'Once, alighting in a park, they found a burned-out mansion and a row of impaled cadavers tottering on a fence.' But lest we think that this is a principled indictment, a little further on 'they saw the countryside grow calm, well tilled, prosperous, coloured by the blue-green of poppy fields' (53). Their new host, the local governor Mustafa Ibrahim Bey, is proud of acquiring some fairies for his needs and he had thought of having 
their wings torn out. Common sense prevailed; none of them showed the slightest inclination to fly away, so why go to extremes?' (62). However, such stereotypical cruelties of the East are here as unreliable as anything else in this fickle world, for Ludo cannot bear to leave this place where "'for the first time in my life I have lived in comfort without fearing and scheming"' (63). In turn, the Governor longs for a friend, "'a disinterested European friend, the real article", and is delighted by Ludo's decision, and the story ends in a way that no reader could have foreseen at the beginning. It is also one in which the ethics of the solution are kept coolly out of the picture.

Warner's technique can be described as ethnographic: a rich description of the local customs of Elfin and human worlds from the perspective of an observer who has access to people's minds, but who tries to be dispassionate and, above all, neutral about what is being observed. In 'The Revolt at Brocéliande', for example, we witness the habits and rituals of a fairy court in Brittany where Queen Melior hits on a new fashion for the court that will emulate the supposed customs of the ancestral fairy courts in Persia: "no one had thought of eunuchs' (66). What ensues is a thick description of this court, castrations included, and the life experiences, by no means merely horrific, of the two changelings chosen to become eunuchs. 'The Late Sir Glamie' explores the theological implications of that impossible thing, a fairy ghost (fairies have no souls and hence no afterlife), and the relative impact of short and long lifespans on human and fairy psychology and social custom. 'Castor and Pollux' features the fairy Hamlet, a 'mental libertine' (207) who adores all things human and their absurdities, among them the theatre. His eager but uncomprehending Elfin wife becomes pregnant by a human actor, and dies inevitably in childbirth, twin humans proving fatal for the fairy birth canal. The twin boys pursue ecclesiastical careers and their father Hamlet founds a theological college for them in which they can indulge their (and his) fascination with theological questions strictly prohibited in fairyland: 'Hamlet could not believe his luck. They were more innocent than the puppets, more wholeheartedly ludicrous than the players. Whatever the cost, he must keep them' (221). 'The Occupation' shows us, in a series of dazzling reversals, the occupation of a parish church and Presbyterian rectory by a group of fairies, who embark on an Elfin ethnography of the parish priest and his life, driving him insane in the process (so much for the non-invasiveness of the ethnographic impulse).

For a decentred ethnographic exploration of social structures and habits of action and feeling, fairies are an excellent vehicle. Fairies have 
a long history of being conceived of as alien to humans, mischievous, cruel, 'an invention that almost wholly lacks moral engagement' ${ }^{9}$ or, in Warner's words, inventions grounded in 'the calm negation on which all Elfindom reposes' (199). While they mirror us, for example in their social stratifications, they are very different from humans, in their longevity, atheism and general amorality. As John Simons has noted, in Kingdoms of Elfin Warner draws on a wide range of historical sources and 'appears to spend as much time on the loving reconstruction of the fine detail of fairy ritual and material culture as she does on the pursuit of the twists and turns of her narrative'. ${ }^{10}$ Warner found this work of 'reconstruction' exhilarating, commenting on a story having 'a great deal of information about Elfhame unknown till now as I have just invented it. Oh, how I long to give it learned footnotes, and references. There is such heartless happiness in scholarship.'11 Kingdoms of Elfin is thus an exuberant ethnography of two communities that share human concerns (love, power, freedom, faith, social custom) while one of these also has a dimension of alien characteristics: inhuman longevity, extreme atheism, freedom from shame and an indifference to human suffering.

Kingdoms of Elfin is certainly unusual in the rigour with which the manipulation of empathy is pursued. But Warner's approach to storytelling also links these stories strongly with her oeuvre as a whole. Kingdoms of Elfin can be seen not so much as a new departure than as the continuation of an ongoing project: how to tell without 'pointing a finger'. Warner's novels Lolly Willowes (1926), Mr Fortune's Maggot (1927), Summer Will Show (1936) and The Flint Anchor (1954), as well as many of her short stories, set out again and again to explore the life-worlds of dispassionately observed individuals. This seems to be the hallmark of her art. Critics have variously described her approach as 'impersonal', 'eccentric' and 'indifferent', favouring an investigation of cognition over a psychology of self or practising besideness rather than a central perspective. ${ }^{12}$ Perhaps Kingdoms of Elfin is most closely connected to The Corner that Held Them (1948), a novel that pursues, scrupulously and minutely, but with barely any of the 'breath of human kindness', the history of a community of medieval nuns as things happen, good, bad, terrible or simply indifferent, in which the potential for emotional drama from individual lives is levelled out by the perspective of time.

This ethnographic approach also differentiates Warner's use of fantasy from that of the mainstream. In her first foray into the fantastic, in Lolly Willowes, the heroine becomes a witch. Kate Macdonald, following Farah Mendlesohn's taxonomy, classifies Lolly Willowes as an 
'estranged fantasy', a 'subdivision of the immersive fantasy', in that it 'immerses the reader into a realist world in which witches happen to live, and the reader finds this quite natural'. ${ }^{13}$ This would also be a good description of Kingdoms of Elfin. After Lolly Willowes, Warner repeatedly resorted to fantasy elements in her writing and seems to have come full circle in Kingdoms of Elfin. As with witchcraft in Lolly Willowes, which draws on contemporary witchcraft scholarship, ${ }^{14}$ Kingdoms of Elfin builds on older Elfin lore, for example the delightful late seventeenthcentury The Secret Commonwealth: An Essay on the Nature and Actions of the Subterranean (and for the Most Part) Invisible People, Heretofore Going Under the Name of Elves, Fauns, and Fairies by the Reverend Robert Kirk, from which Warner quotes extensively. Kingdoms of Elfin is also a forerunner to the explosion of fantasy stories in the present day that revolve around fairy courts; genre writing that finds its place alongside vampire, werewolf or magician stories and their seductions and gratifications. ${ }^{15}$ Today's fairy fantasies, too, tend to foreground the alienness and potential cruelty of fairy worlds, for instance in Charles de Lint's The Wild Wood (1994), Neil Gaiman's Stardust (1999), Susanna Clarke's Jonathan Strange and Mr Norrell (2004) and Holly Black's fairy trilogy beginning with Tithe (2002). However, they often follow models that are centred on and told from a specific perspective, often built on a hero's quest motif. Almost inevitably, they give us a character to identify with, human or fairy, either in first-person narratives or in third-person narratives offering a strongly foregrounded point of view for the reader to enter. ${ }^{16}$ This is precisely what Warner's stories seem to be designed to actively prevent, and in 'The Power of Cookery', which favours the art of good cooking over romance questing, this scepticism becomes explicit. Love and desire are still at the heart of many of her stories, but these do not function as the narrative fulfilment, unlike the essentially identitycentred recognition structures created by later fairy fantasists.

Continuing to explore the theme of love in Warner's writing, it is clear that her stories dwell on a question that has recurred throughout her oeuvre (particularly in Mr Fortune's Maggot): What exactly is the connection, adverse or causal, between love and freedom? 'Elphenor and Weasel' relates how a wandering fairy couple's enjoyment of the human world depends precisely on those things that result from the shortness of human lifespans. This is explicitly linked to the recklessness of their love, which ends with an ordeal where 'death by lightning would have been easier' (42) as the price to pay for the ecstatic freedom that comes with love. 'Winged Creatures' follows other doomed but exhilarating loves and longings. Lady Fidès, for example, fails to 
become a bird, but invests birds with all of her love, above even the love of her child: 'Love was what she felt for birds - a free gift, unrequired, unrequited, invulnerable' (141). Gobelet the changeling in turn enjoys a short spell of bliss with Lady Fidès's fairy son Grive - the French name for a thrush, but also only one letter less than grieve - who for a time provides the greatest attachment and at the same time the greatest freedom of his life.

With that morning Gobelet began the happiest epoch of his life. As nearly as possible, he became a fairy. He lost all sense of virtue and responsibility and lived by pleasures - pell-mell pleasures: a doubled rainbow, roasting a hedgehog. (150)

This story provides a marvellously complex opening of the imagination on matters of desire, need, freedom and constraint, where nothing is ever tied down. 'Foxcastle', the story that closes the collection, resonates forcefully with Warner's lifelong concern in her fictions, and arguably also in her life: how to be, become and make one another free. The story centres on a human who is captured and studied by fairies. Ultimately indifferent to him and what knowledge he can give them, the fairies quickly lose interest and the protagonist remains in Elfindom until his visible ageing makes him noticeably undesirable and he is returned as an old man to the human world again. For him, the experience is a revelation of freedom that results, quite in contrast to 'Elphenor and Weasel', not from the reckless bliss of love but rather from the promise of detachment.

For by the simple act of discarding his fetters and walking up a winding stair he had attained the wish of his heart. Watching these happy beings for whom weeping was impossible, he had become incapable of grief; watching their inconsistencies, he had become incapable of knowing right from wrong; disregarded by them he had become incapable of disappointment [...] he lived in a perpetual present. (258-9)

When he returns to his own kind, he totters towards some passers-by 'making noises' which they fail to understand, for he 'had lived so long with the fairies he had forgotten his native speech'. Our last sighting is of someone giving him some alms with the instruction that returns us abruptly to how humans do things: "Take it, take it," said the gentleman, "Go away, and be grateful"” (261). 
What we see in Kingdoms of Elfin and what characterises Warner's oeuvre as a whole, is a remarkable degree of artistic independence that has consistently led to the somewhat bemused recognition with which so many appreciations of her work start: a 'commonplace of criticism', ${ }^{17}$ that she has been inexplicably neglected. In Claire Harman's words, not unlike the fairy creatures she created who remain for the most part unseen to human eyes, Warner seems like 'a ghostly figure in twentiethcentury letters'. ${ }^{18}$ This independence can also be seen in her life as she seems to have weathered challenges and changes without fuss and without losing sight of what was important to her. Luckily for readers of her fiction, much of her life can be found in Warner's correspondence, her diaries and Harman's luminous account of her life.

Sylvia Townsend Warner was born in 1893 into a family both privileged and intellectually stimulating. Her father, George Townsend Warner, was, by all accounts, an exceptionally gifted teacher of history at Harrow School. ${ }^{19}$ Warner herself was first educated by her mother Eleanor Mary Townsend Warner, née Hudleston, who seems to have had little interest in her daughter once she began to grow up because, as Warner thought, she was not a son. ${ }^{20}$ Warner seems to have been very close to her father. Claire Harman's biography includes a haunting photograph of a teenage Sylvia skating with her father, a beautiful image of mutual grace and consideration as they are poised together in a spin, holding onto each other but also pursuing their own trajectories. The task of educating their only child moved from Warner's mother to her father. As a result, she had access to her father's considerable library as well as his expertise as a historian and as a teacher, and as a meticulous stylist in both writing and speech. This meant that she received an excellent education: 'By the age of seventeen or so, Sylvia's erudition was both phenomenal and perfectly natural. In the opinion of some, she was "the cleverest fellow we had", to others she was known somewhat disparagingly - as the best boy at Harrow.' ${ }^{21}$ It also meant that Warner completely escaped formal educational disciplines, schools, curricula and the influence of the state in determining what young people should learn and read.

Warner maintained a close allegiance to historiography throughout her writing life: Kingdoms of Elfin is, among other things, an exploration of historical, regional and national environments. ${ }^{22}$ 'History' here means an especial commitment to historical materialism, the belief that the material lives of people, where their food comes from, how their money is earned, what their clothing is made of, as well as the general habits of a specific class or group, are instrumental 
in influencing what can be thought, felt and communicated, and how. Warner returned repeatedly to different forms of the historical novel, for example her exploration of the February 1848 revolution in France in Summer Will Show, medieval England in The Corner that Held Them and the world of the nineteenth century in The Flint Anchor. At the same time, however, she would retain the autodidact's freedom to bypass prescribed ideas of the canon. In her lecture on the historical novel Warner claimed that 'when I was young, I read everything in the house', ${ }^{23}$ and this seems to have set her free to seek and find inspiration where she felt she would find it.

In her lecture 'Women as Writers' (1959), Warner set out to demonstrate not so much that women wrote, still less who the 'great' women writers were, if any existed, but rather how they wrote, claiming that they were 'remarkably adept at vanishing out of their writing so that the quality of immediacy replaces them'. ${ }^{24}$ She gleefully demonstrates this 'immediacy' - a quality which she associates with the egoless artistry of women writers and values highly - with quotations from women's voices in non-canonical sources: a cookery book, Florence Nightingale's reports from the front, a fifteenth-century letter, Julian of Norwich's description of her perception of God. This virtue of 'immediacy' is very much a virtue of style, of a non-fussy 'immediate' use of language, and Warner would have been her own best example. In a complicated irony she sees immediacy as the special domain of the marginalised woman writer, writers who eschew the pointing finger and dispense with trying to be 'literary' altogether, since this is tacitly reserved for male writers:

But I have sometimes wondered if women are literary at all. It is not a thing which is strenuously required of them, and perhaps, finding something not required of them, they thank God and do no more about it. They write. They dive into writing like ducks into water. One would almost think it came naturally to them - at any rate as naturally as plain sewing. ${ }^{25}$

Her first intellectual love, however, was directed more towards music than writing. In 1917 she was appointed to the editorial committee of the Tudor Church Music Project, on which she worked for 12 years. As late as 1975, at the end of a long writing career, she would describe herself as 'that odd thing, a musicologist'. ${ }^{26}$ She moved to London and, alongside working on Tudor church music, began a life of writing in earnest. In 1925 she published her first collection of poems, The 
Espalier, and her first novel in 1926, Lolly Willowes, which became a Book of the Month in the USA. She continued to publish poetry alongside novels and short stories (many published in the New Yorker from 1936 on). Later in life, she also translated from the French: A Place of Shipwreck, a translation of Jean-René Huguenin's La Côte Sauvage (1962), and By Way of Sainte-Beuve (a translation of Marcel Proust's Contre Sainte-Beuve, 1967). In 1967 she published a commissioned biography of the acclaimed and troubled English writer T. H. White. While her status as a literary figure may have been on the margins rather than at the centre, she maintained a distinguished career and her long collaboration with the New Yorker ensured some financial stability. She was a regular contributor of stories for the newspaper and was free to pursue her art without considering too much what her market was willing to accept. This makes the assignment of her work to one 'school' or another difficult, and may have hindered her scholarly reception, as this is notoriously category-dependent. Yet Warner's works have always had faithful readers and this republication of Kingdoms of Elfin by Handheld Press gives new readers the opportunity to encounter her original, engaging and challenging writing.

In 1930, at the age of 37, Warner moved in with and became the lover of the poet Valentine Ackland, the woman who would become the love of her life. At this point, Warner's only long-term relationship had been with the musician Percy Carter Buck, with whom she had begun a secret affair when she was 19 . He was married, 22 years older than her and had five children, and he had been her music teacher since she was 16. ${ }^{27}$ Falling in love with a woman should have been a momentous shift of direction in terms of Warner's sense of identity - she was, after all, now the lover of a woman 13 years her junior, who was a rather dashing cross-dresser as well. They lived together in Dorset for the rest of their lives. The story 'A Love Match', from her collection A Stranger with a Bag (1966), which displaces the sexual transgression from lesbianism to incest, provides the wry assertion that one did not have to move to Paris's left bank if one wanted to pursue an unorthodox relationship; one could stay right where one was and count on the general inertia of one's neighbours.

Their relationship began at a time when far greater dangers than lesbianism were looming on the horizon. The two women, like many anti-fascists of the period, joined the Communist Party of Great Britain in 1935. During the Spanish Civil War they joined a Red Cross unit and were active in the 1937 International Association of Writers for the Defence of Culture. ${ }^{28}$ Warner's political commitment found 
its expression for a while in an active involvement in communist activities and in general anti-fascist work. ${ }^{29}$ We can also see the effect of her unfailing adherence to her father's passion for history, in her case with an unwavering commitment to historical materialism as she explores, ${ }^{30}$ with an unfailing precision of vision, how we come to be who we are through the forces of society, class and history. At the same time, her stories often revolve around the question of how a person might escape from these constraints rather than be defined by them.

In general, there is a free-spiritedness and independentmindedness in Warner's life choices that seem in tune with the cool matter-of-factness of the ethnographic gaze in her fictions. Her narrative voice rarely registers outrage or surprise at even the most unusual behaviours exhibited by her fictional creatures: 'She had the knack of melting across barriers, rather than defining herself against them. ${ }^{31}$ Her relationship with Valentine was troubled by Valentine's tumultuous affair with the American scholar Elizabeth Wade White, as well as Valentine's addiction to alcohol. ${ }^{32}$ But their relationship was Warner's life's project: exploring how freedom could be reconciled with love. While she felt that many of their letters could not be published as long as people mentioned in them were still alive, after Valentine's death in 1969 Warner spent much time sorting and arranging their lives' correspondence, constructing an autobiographical framework for their story and preserving the history of their love. The edited letters, which would eventually be published posthumously as I'll Stand by You (1998), are a moving and lucid account of a relationship and an important contribution to the archive of lesbian history, of which there is so much need for development and in which there are so few entries. ${ }^{33}$

Warner's two parallel literary occupations at the end of her life seem diametrically opposed: the painstaking and grief-driven autobiographical reconstruction of her and Valentine's lives in letters and the composition of the stories that would make up Kingdoms of Elfin. These stories are so alien to human concerns that it has been surmised that Warner may have 'wanted a change even from warm-bloodedness'. ${ }^{34}$ Indeed, the collection is profoundly disturbing because the centre of perception, value and vision is not human, but has been replaced with a complex set of mutual observations, amusements, cruelties and simple incomprehensions. ${ }^{35}$ The empathy Warner withdrew from her storytelling may be supplied by her human readers, who may feel that the stories, after all, critique cruelty and do side with human suffering. ${ }^{36}$ 
Jennifer Poulos Nesbitt, for example, produces the following reading of the ending of 'Elphenor and Weasel':

No one could account for them, or for the curious weightless fragments of a substance rather like sheet gelatine which the wind had scattered over the floor. They were buried in the same grave. Because of their small stature and light bones they were entered in the Register of Burials as Two Stranger Children.

The verb account [...] marks failures of imagination and sympathy for those outside the community. No curiosity is voiced about the excess matter, and their bodies are classified erroneously in an effort to dismiss their incongruity. ${ }^{37}$

'Failures of imagination and sympathy for those outside the community', 'an effort to dismiss': the passage (and those preceding it) censures the characters in the story for their active indifference. But the narration Warner offers simply states what happened: that one species' suffering may be a matter of indifference to another species, and not only among fairies. At the same time, the humans in the story, in contrast to the readers, are not privy to the extraordinary flowering of love between Elphenor and Weasel so that this ending also ensures that the secrets of the fairies are guarded from intrusive sympathy from creatures who are of next to no account to them. Positing the non-dominance, even the irrelevance, of humans, is Warner's startling anticipation of the 'post-human' moment: the realisation, which we are arriving at only now through an awareness of our Anthropocene age, that human beings are not the centre of the universe and that they need to explore and accommodate themselves to this fact. 'Bother the human heart' becomes a parting instruction as well as an indictment. This last phase of her writing was indeed 'Something Entirely Different'.

\section{Notes}

1 Sylvia Townsend Warner, 'In Conversation with Val Warner and Michael Schmidt in 1975' (1981), in With the Hunted: Selected Writings, ed. Peter Tolhurst (Norwich: Black Dog Books, 2012), pp. 402-3.

2 Michael Steinman (ed.), The Element of Lavishness: Letters of Sylvia Townsend Warner and William Maxwell, 1938-1978
(New York: Counterpoint 2004), p. 216.

3 Vike Martina Plock, 'A Note on Sylvia Townsend Warner's "The Kingdom of Elfin" (1927)', Journal of the Sylvia Townsend Warner Society 2015, pp. 6-8.

4 Warner's letter to William Maxwell, in Steinman, The Element of Lavishness, p. 215. 
5 Page numbers within the text of the article come from Kingdoms of Elfin (Bath: Handheld Press, 2018).

6 Helen Sutherland, 'From Elphame to Otherwhere: Sylvia Townsend Warner's Kingdoms of Elfin', Journal of the Sylvia Townsend Warner Society 2005, p. 26.

7 Rebecca Hahn, 'Sidestepping Normativity: The Short Stories of Sylvia Townsend Warner'. Dissertation, University of Tübingen, 2017, p. 173.

8 Quoted in Melanie Micir, "Living in Two Tenses": The Intimate Archives of Sylvia Townsend Warner', Journal of Modern Literature 36 (2012), p. 126.

9 Diane Purkiss, At the Bottom of the Garden: A Dark History of Fairies, Hobgoblins, and Other Troublesome Things (New York: New York University Press, 2000), p. 8; Carole G. Silver, Strange and Secret Peoples: Fairies and Victorian Consciousness (Oxford: Oxford University Press, 1999), pp. 149-84 on Victorian fairy cruelties.

10 John Simons, 'On the Compositional Genetics of the Kingdom of Elfin together with a Note on Tortoises', in Gill Davies, David Malcolm and John Simons (eds.), Critical Essays on Sylvia Townsend Warner, English Novelist 1893-1978 (Lewiston, NY: Edwin Mellen, 2006), p. 47.

11 Quoted in Simons, 'On the Compositional Genetics of the Kingdom of Elfin', p. 47.

12 For example, David James, 'Realism, Late Modernist Abstraction, and Sylvia Townsend Warner's Fictions of Impersonality', Modernism/Modernity 12.1 (2005), pp. 111-31; James Harker, "Laura was Not Thinking": Cognitive Minimalism in Sylvia Townsend Warner's Lolly Willowes', Studies in the Novel 46 (2014), pp. 44-62; Hahn, 'Sidestepping Normativity'.

13 Kate Macdonald, 'Witchcraft and Non-Conformity in Sylvia Townsend Warner's Lolly Willowes (1926) and John Buchan's Witch Wood (1927)', Journal of the Fantastic in the Arts 23 (2012), p. 224.

14 Miriam Wallraven, Women Writers and the Occult in Literature and Culture: Female Lucifers, Priestesses, and Witches (New York: Routledge, 2015).

15 On the continuity today between fairy and vampire worlds, see Purkiss, At the Bottom of the Garden, pp. 321-2.

16 See, for example, Ellen Datlow and Terri Windling (eds.), The Faery Reel: Tales from the Twilight Realm (New York: Viking Books, 2004).

17 Elizabeth Powers, 'On Situating Sylvia Townsend Warner: How (Not) to Become a "Classic" Writer', Yale Review 104 (2016), p. 88.

18 Claire Harman, 'Introduction', in Sylvia Townsend Warner, New Collected Poems (Manchester: Carcanet, 2008), p. 1.

19 Claire Harman, Sylvia Townsend Warner: A Biography (1989; London: Penguin, 2015), p. 20; Rosemary Sykes, “This was a Lesson in History": Sylvia Townsend Warner, George Townsend Warner and the Matter of History', in Davies, Malcolm and Simons (eds.), Critical Essays, pp. 103-15.

20 Harman, Sylvia Townsend Warner: A Biography, p. 13.

21 Harman, Sylvia Townsend Warner: A Biography, p. 20.

22 See Sutherland, 'From Elphame to Otherwhere'.

23 Sylvia Townsend Warner, 'The Historical Novel' (1940), in With the Hunted, p. 268.

24 Sylvia Townsend Warner, 'Women as Writers' (1959), in With the Hunted, p. 236.

25 Warner, With the Hunted, p. 234.

26 Warner, With the Hunted, p. 399.

27 Harman, Sylvia Townsend Warner: A Biography, p. 24.

28 Arnold Rattenbury, 'Literature, Lying and Sober Truth: Attitudes to the Work of Patrick Hamilton and Sylvia Townsend Warner', in John Lucas (ed.), Writing and Radicalism (London and New York: Longman, 1996), pp. 220-2.

29 Kristin Ewins, 'The Question of Socialist Writing and Sylvia Townsend Warner in the Thirties', Literature Compass 5 (2008), pp. 657-67; Maroula Joannou, "Our Time": Sylvia Townsend Warner, Virginia Woolf and the 1940s', Literature Compass 11 (2014), pp. 732-44.

30 See Sykes, "This was a Lesson in History"; Joannou, “'Our Time”; and Melanie Micir, "Not of National Importance: Sylvia Townsend Warner, Women's Work, and the Mid-Century Historical Novel', in Allan Hepburn (ed.), Around 1945: Literature, Citizenship, Rights (Montreal and Kingston: McGillQueen's University Press, 2016), pp. 66-83.

31 Adam Mars-Jones, 'Introduction', in Sylvia Townsend Warner, Mr Fortune's Maggot and The Salutation 
(New York: New York Review of Books, 2001), p. ix.

32 See Peter Haring Judd, The Akeing Heart: Letters between Sylvia Townsend Warner, Valentine Ackland and Elizabeth Wade White (Reading: Handheld Press, 2018).

33 Micir, "Living in Two Tenses", p. 2018.

34 Warner, Mr Fortune's Maggot and The Salutation, p. xiii.

35 Rebecca Hahn, 'Encounters between Elves and Humans in Sylvia Townsend Warner's Kingdoms of Elfin', Journal of the Sylvia Townsend Warner Society 2010, pp. 53-68.

36 Hannah Priest, "The Unnaturalness of a Society: Class Divisions and Conflict in Sylvia Townsend Warner's Kingdoms of Elfin', Journal of the Sylvia Townsend Warner Society 2010, pp. 1-16.

37 Jennifer Poulos Nesbitt, Narrative Settlements: Geographies of British Women's Fiction between the Wars (Toronto: University of Toronto Press, 2005), pp. 107-8.

\section{Bibliography}

Bingham, Frances. 'The Practice of the Presence of Valentine: Ackland in Warner's Work', in Gill Davies, David Malcolm and John Simons (eds.), Critical Essays on Sylvia Townsend Warner, English Novelist 1893-1978 (Lewiston, NY: Edwin Mellen, 2006), pp. 29-44.

Datlow, Ellen, and Terri Windling (eds.). The Faery Reel: Tales from the Twilight Realm (New York: Viking Books, 2004).

Ewins, Kristin. 'The Question of Socialist Writing and Sylvia Townsend Warner in the Thirties', Literature Compass 5 (2008), pp. 657-67.

Hahn, Rebecca. 'Encounters between Elves and Humans in Sylvia Townsend Warner's Kingdoms of Elfin', Journal of the Sylvia Townsend Warner Society 2010, pp. 53-68.

Hahn, Rebecca. 'Sidestepping Normativity: The Short Stories of Sylvia Townsend Warner'. Dissertation, University of Tübingen, 2017.

Harker, James. "Laura was Not Thinking": Cognitive Minimalism in Sylvia Townsend Warner's Lolly Willowes', Studies in the Novel 46 (2014), pp. 44-62.

Harman, Claire. 'Introduction', in Sylvia Townsend Warner, New Collected Poems (Manchester: Carcanet Press, 2008), pp. 1-11.

Harman, Claire. Sylvia Townsend Warner: A Biography (1989; London: Penguin, 2015).

James, David. 'Realism, Late Modernist Abstraction, and Sylvia

Townsend Warner's Fictions of Impersonality', Modernism/Modernity 12.1 (2005), pp. 111-31.

Joannou, Maroula. “'Our Time”: Sylvia Townsend Warner, Virginia Woolf and the 1940s', Literature Compass 11 (2014), pp. 732-44. 
Judd, Peter Haring. The Akeing Heart: Letters between Sylvia Townsend Warner, Valentine Ackland and Elizabeth Wade White (Reading: Handheld Press, 2018).

Macdonald, Kate. 'Witchcraft and Non-Conformity in Sylvia Townsend Warner's Lolly Willowes (1926) and John Buchan's Witch Wood (1927)', Journal of the Fantastic in the Arts 23 (2012), pp. 215-38.

Mars-Jones, Adam. 'Introduction', in Sylvia Townsend Warner, $\mathrm{Mr}$ Fortune's Maggot and The Salutation (New York: New York Review of Books, 2001), pp. vii-xiii.

Micir, Melanie. "Living in Two Tenses": The Intimate Archives of Sylvia Townsend Warner', Journal of Modern Literature 36 (2012), pp. 119-31.

Micir, Melanie. 'Not of National Importance: Sylvia Townsend Warner, Women's Work, and the Mid-Century Historical Novel', in Allan Hepburn (ed.), Around 1945: Literature, Citizenship, Rights (Montreal and Kingston: McGill-Queen's University Press, 2016), pp. 66-83.

Montefiore, Janet. 'Sylvia Townsend Warner Scholarship 1978-2013', Literature Compass 11/12 (2014), pp. 786-811.

Nesbitt, Jennifer Poulos. Narrative Settlements: Geographies of British Women's Fiction between the Wars (Toronto: University of Toronto Press, 2005).

Plock, Vike Martina. 'A Note on Sylvia Townsend Warner's "The Kingdom of Elfin" (1927)', Journal of the Sylvia Townsend Warner Society 2015, pp. 6-8.

Powers, Elizabeth. 'On Situating Sylvia Townsend Warner: How (Not) to Become a "Classic" Writer', Yale Review 104 (2016), pp. 88-100.

Priest, Hannah. 'The Unnaturalness of a Society: Class Divisions and Conflict in Sylvia Townsend Warner's Kingdoms of Elfin', Journal of the Sylvia Townsend Warner Society 2010, pp. 1-16.

Purkiss, Diane. At the Bottom of the Garden: A Dark History of Fairies, Hobgoblins, and Other Troublesome Things (New York: New York University Press, 2000).

Rattenbury, Arnold. 'Literature, Lying and Sober Truth: Attitudes to the Work of Patrick Hamilton and Sylvia Townsend Warner', in John Lucas (ed.), Writing and Radicalism (London and New York: Longman, 1996), pp. 201-44.

Silver, Carole G. Strange and Secret Peoples: Fairies and Victorian Consciousness (Oxford: Oxford University Press, 1999).

Simons, John. 'On the Compositional Genetics of the Kingdom of Elfin together with a Note on Tortoises', in Gill Davies, David Malcolm and John Simons (eds.), Critical Essays on Sylvia Townsend Warner, 
English Novelist 1893-1978 (Lewiston, NY: Edwin Mellen, 2006), pp. 45-60.

Steinman, Michael (ed.). The Element of Lavishness: Letters of Sylvia Townsend Warner and William Maxwell, 1938-1978 (New York: Counterpoint, 2001).

Sutherland, Helen. 'From Elphame to Otherwhere: Sylvia Townsend Warner's Kingdoms of Elfin', Journal of the Sylvia Townsend Warner Society 2005, pp. 21-32.

Sykes, Rosemary. "This was a Lesson in History": Sylvia Townsend Warner, George Townsend Warner and the Matter of History', in Gill Davies, David Malcolm and John Simons (eds.), Critical Essays on Sylvia Townsend Warner, English Novelist 1893-1978 (Lewiston, NY: Edwin Mellen, 2006), pp. 103-15.

Wallraven, Miriam. Women Writers and the Occult in Literature and Culture: Female Lucifers, Priestesses, and Witches (New York: Routledge, 2015).

Warner, Sylvia Townsend. I'll Stand By You: Letters of Sylvia Townsend Warner and Valentine Ackland, ed. Susanna Pinney (London: Random House, 1998).

Warner, Sylvia Townsend. 'The Historical Novel' (1940), in With the Hunted: Selected Writings, ed. Peter Tolhurst (Norwich: Black Dog Books, 2012), pp. 268-70.

Warner, Sylvia Townsend. 'In Conversation with Val Warner and Michael Schmidt in 1975' (1981), in With the Hunted: Selected Writings, ed. Peter Tolhurst (Norwich: Black Dog Books, 2012), pp. 399-406.

Warner, Sylvia Townsend. 'Women as Writers' (1959), in With the Hunted: Selected Writings, ed. Peter Tolhurst (Norwich: Black Dog Books, 2012), pp. 231-40.

\section{Notes on contributor}

Ingrid Hotz-Davies is Professor of English Literature and Gender Studies at the University of Tübingen in Germany. She is especially interested in women's writing, early modern literature, queer/gender theory and literary practice, and the study of affect in literature. She has published on a variety of issues in these fields, from the uses of camp or shame to the affordances of religious poetry for women writers. 